\title{
Determination of Saturated Concentration and Diffusion Coefficient of Nitric Oxide in Physiological pH Solution Using Hydrodynamic Chronocoulometry
}

\author{
Tadato ORITANI, Takeyoshi OKAJIMA, and Takeo OHSAKA*
}

Department of Electronic Chemistry, Interdisciplinary Graduate School of Science and Fngineering, Tokyo Institute of Technology (Mail Box G1-5, 4259 Nagatsuta, Midori-ku, Yokohama 226-8502, Japan)

Received December 18, 2003 ; Accepted March 11, 2004

\begin{abstract}
Electro-oxidation reaction of NO in phosphate buffer solution $\left(0.1 \mathrm{M}\left(1 \mathrm{M}=1 \mathrm{~mol} \mathrm{dm}^{-3}\right)\right.$, $\left.\mathrm{pH} 7.2\right)$ containing its oxidized species, electroactive $\mathrm{NO}_{2}{ }^{-}$, has been investigated using cyclic and linear sweep voltammetry with electrochemically pretreated $\mathrm{Au}, \mathrm{Pt}$, and glassy carbon electrodes. Well-separated oxidation peaks for $\mathrm{NO}$ and $\mathrm{NO}_{2}{ }^{-}$could be observed at these pretreated electrodes. Thus the values of saturated concentration $\left(C_{\mathrm{No}}\right)$ and diffusion coefficient $\left(D_{\mathrm{NO}}\right)$ of NO were simultaneously determined to be $1.7 \pm 0.1 \mathrm{mM}$ and $(1.3 \pm 0.1) \times 10^{-5} \mathrm{~cm}^{2} \mathrm{~s}^{-1}$, respectively, using hydrodynamic chronocoulometry. The values obtained are briefly discussed on the basis of comparison with those previously reported.
\end{abstract}

Key Words : Nitric Oxide, Saturated Concentration, Diffusion Coefficient, Hydrodynamic Chronocoulometry

\section{Introduction}

In this communication, we report the determination of the diffusion coefficient $\left(D_{\mathrm{NO}}\right)$ and saturated concentration $\left(C_{\mathrm{NO}}\right)$ of nitric oxide $(\mathrm{NO})$ in physiological $\mathrm{pH}$ solution, to the study in biological systems of which a great deal of attention has been devoted because of its important biological role as a potent endogeneous vasodilator ${ }^{\text {. }}$ as well as in inflammation, thrombsis, immunity and neurotransmission. ${ }^{1)}$ Knowledge of $D_{\mathrm{NO}}$ and $C_{\mathrm{NO}}$ is essential to the analysis of an electrochemical system of NO from the viewpoints of electrode kinetics and electroanalytical chemistry. We have applied hydrodynamic chronocoulometry ( $\mathrm{HCC}$ ) to estimate $D_{\mathrm{NO}}$ and $C_{\mathrm{NO}}$, because it allows simultaneous determination of $D_{\mathrm{NO}}$ and $n C_{\mathrm{NO}}$ ( $n$ : the number of electrons involved in the electrode reaction of NO and in this case $n=1$ ) without previous knowledge of either of them from a single experiment. The precise formulation of HCC has been reported by our group, and successfully applied to determine the diffusion coefficients and the saturated concentrations of molecular oxygen $\left(\mathrm{O}_{2}\right)$ and superoxide ion in various media. ${ }^{2-4)}$ The half-life of $\mathrm{NO}$ is very short, e.g., $c a .6 \mathrm{~s}$ in physiological solutions, ${ }^{5)}$ but NO was found to be stable in the present experimental time scale ( $c a .15 \mathrm{~min}$ ) and NO is liable to be oxidized by $\mathrm{O}_{2}$ to nitrite $\left(\mathrm{NO}_{2}^{-}\right)$and nitrate $\left(\mathrm{NO}_{3}{ }^{-}\right){ }^{1,5-7)}$ This is the reason why HCC was preferably employed for determination of $D_{\mathrm{NO}}$ and $C_{\mathrm{NO}}$ in this study.

\section{Experimental}

NO-saturated solution was prepared by bubbling NO gas $(99.0 \%$, TOHO SANSO KOGYO, Japan) through deoxygenated phosphate buffer $(\mathrm{pH} 7.2)$ for $20 \mathrm{~min}$. $0.1 \mathrm{M}$ Phosphate buffer ( $\mathrm{pH}$ 7.2) solutions were prepared from deionized water (Milli-Q system, Millipore, Japan) using $\mathrm{Na}_{2} \mathrm{HPO}_{4}$ and $\mathrm{NaH}_{2} \mathrm{PO}_{4}$ salts (KANTO Chemical Co.). All other chemicals used in this study were of analytical grade and used as received.

The electrochemical measurements were performed in a conventional three-electrode system with $\mathrm{Au}, \mathrm{Pt}$ and glassy carbon (GC) working electrodes, a spiral Pt wire auxiliary electrode, and a potassium chloride saturated silver/silver chloride $(\mathrm{Ag} / \mathrm{AgCl})$ reference electrode. $\mathrm{Au}$ (diameter, $d=1.6 \mathrm{~mm})$ and Pt $(d=2.0 \mathrm{~mm})$ disk electrodes were polished with alumina powder and then were electrochemically cleaned. GC disk electrodes of $3.0 \mathrm{~mm}$ diameter were also polished with alumina powder and then were electrochemically pretreated. ${ }^{8)}$ Cyclic voltammetry and hydrodynamic chronocoulometry were carried out using a computer-controlled electrochemical analyzer (BAS $100 \mathrm{~B} / \mathrm{W}$ ) and a rotating disk electrode system from Nikko Keisoku, Japan according to the same procedure as previously reported. ${ }^{2-4}$ During all the electrochemical measurements, Ar gas (99.9999\%, Nippon SANSO Co.) was flushed over the NO-saturated cell solution.

The value of kinematic viscosity $(v)$ of the NOsaturated phosphate buffer solution was measured at 25.0 $\pm 0.1^{\circ} \mathrm{C}$ in a thermostated water bath using an Ubbellohde viscometer. The $v$ value was $(9.23 \pm 0.10) \times 10^{-3} \mathrm{~cm}^{2}$ $\mathrm{s}^{-1}$.

\section{Results and Discussion}

NO-saturated solutions are prepared under anaerobic conditions using phosphate buffer solution deoxygenated with $\mathrm{Ar}$ gas. However, water-soluble oxidation products of $\mathrm{NO}$ can form even if trace quantities of $\mathrm{O}_{2}$ are present in the solution. It has been reported that NO reacts with 
$\mathrm{O}_{2}$ to produce nitrogen dioxide $\left(\mathrm{NO}_{2}\right)$ (Eq. 1), and $\mathrm{NO}_{2}$ immediately reacts again with $\mathrm{NO}$ at an almost diffusioncontrolled rate $\left(k_{2}>10^{9} \mathrm{M}^{-1} \mathrm{~s}^{-1}\right)$ to produce $\mathrm{NO}_{2}^{-}$(Eq. 2) or disproportionates to $\mathrm{NO}_{2}^{-}$and $\mathrm{NO}_{3}{ }^{-}$(Eq. 3) in physiological $\mathrm{pH}$ solution. ${ }^{6,7,9}$

$$
\begin{gathered}
2 \mathrm{NO}+\mathrm{O}_{2} \underset{k_{-1}}{\stackrel{k_{1}}{\longrightarrow}} 2 \mathrm{NO}_{2} \\
\mathrm{NO}+\mathrm{NO}_{2}+\mathrm{H}_{2} \mathrm{O} \stackrel{k_{2}}{\longrightarrow} 2 \mathrm{NO}_{2}{ }^{-}+2 \mathrm{H}^{+} \\
2 \mathrm{NO}_{2}+\mathrm{H}_{2} \mathrm{O} \stackrel{k_{3}}{\longrightarrow} \mathrm{NO}_{2}{ }^{-}+\mathrm{NO}_{3}{ }^{-}+2 \mathrm{H}^{+}
\end{gathered}
$$

Therefore, $\mathrm{NO}, \mathrm{NO}_{2}{ }^{-}$and $\mathrm{NO}_{3}{ }^{-}$are considered to coexist in the NO-saturated solution used in this work.

Figure 1A shows the typical voltammograms of NO obtained at a bare Au electrode in $0.1 \mathrm{M}$ phosphate buffer solution. Two well-separated oxidation peaks, $E_{\mathrm{p} 1}^{\mathrm{a}}$ and $E_{\mathrm{p} 2}^{\mathrm{a}}$, were observed at 0.65 and $0.82 \mathrm{~V}$ vs. $\mathrm{Ag} / \mathrm{AgCl}$, respectively. These well-separated oxidation peaks could not be obtained when the electrochemically unpretreated (i.e., uncleaned) electrodes were used. This is because the oxidations of $\mathrm{NO}$ and $\mathrm{NO}_{2}{ }^{-}$occur at a close potential and they overlap each other at uncleaned electrodes. ${ }^{10)}$ In order to identify these two oxidation reactions, $\mathrm{Ar}$ gas was purged into the solution immediately after the voltammogram shown in Fig. 1A(a) was recorded. The oxidation peak at $E_{\mathrm{pl}}^{\mathrm{a}}$ totally disappeared after $\mathrm{Ar}$ gas was sufficiently purged (Fig. 1A(b)). This fact suggests that the oxidation peak at $E^{\mathrm{a}}{ }_{\mathrm{p} 1}$ would be due to the oxidation of dissolved NO gas (Eq. $4^{11)}$ ).

$$
\begin{gathered}
\mathrm{NO}+\mathrm{H}_{2} \mathrm{O} \longrightarrow \mathrm{NO}_{2}{ }^{-}+2 \mathrm{H}^{+}+\mathrm{e}^{-} \\
\mathrm{NO}_{2}{ }^{-}+\mathrm{H}_{2} \mathrm{O} \longrightarrow \mathrm{NO}_{3}{ }^{-}+2 \mathrm{H}^{+}+2 \mathrm{e}^{-}
\end{gathered}
$$

However, the oxidation peak at $E_{\mathrm{p} 2}^{\mathrm{a}}$ (Eq. $\left.5,{ }^{12)}\right)$ was still observed on the voltammogram (see the inset in Fig. 1A). Addition of $\mathrm{NO}_{2}{ }^{-}$into the $\mathrm{NO}$-saturated solution led to the increase of the oxidation peak current at $E_{\mathrm{p} 2}^{\mathrm{a}}$ as shown in Fig. 1B. In the potential region from 0.65 to $1.00 \mathrm{~V}$, the oxide layer formation on gold as well as platinum electrode surfaces takes place as shown by the dotted line in Fig. 1B. ${ }^{8)}$ Therefore, the oxidation peak $E_{\mathrm{p} 2}^{\mathrm{a}}$ is considered to be based on the overlapping of both the oxidation of $\mathrm{NO}_{2}^{-}$produced in the above-mentioned pathway (Eqs. 1-3) and the oxide layer formation. That is why $\mathrm{GC}$ electrode has been employed for the simultaneous quantitative detection of $\mathrm{NO}$ and $\mathrm{NO}_{2}{ }^{-}$in our previous work. ${ }^{8)}$ On the other hand, the oxidation peak $E_{\mathrm{p} 1}^{\mathrm{a}}$ remained unchanged before and after the addition of $\mathrm{NO}_{2}{ }^{-}$anion (see the inset in Fig. 1B). Meanwhile $\mathrm{NO}_{3}{ }^{-}$ is an electroinactive species in the examined potential region. Thus the electrode pretreatment and the appropriate selection of potential region allowed us to apply $\mathrm{HCC}$ to the estimation of $C_{\mathrm{NO}}$ and $D_{\mathrm{NO}}$ of NO dissolved in 0.1 $\mathrm{M}$ phosphate buffer solution as mentioned below.

Figure 2 shows the typical steady-state voltammogram obtained for NO oxidation at the rotating GC disk electrode at $200 \mathrm{rpm}$. The RDE voltammetric measurements were performed to determine the range of potential step and of the electrode rotation rate for HCC. At that time, it was found that $\mathrm{NO}$ was stable in this RDE voltammetric time scale ( $c a .15 \mathrm{~min}$ ). At electrode rotation rates of more than $450 \mathrm{rpm}$, the voltammogram became illdefined because of the overlapping of the oxidation waves of $\mathrm{NO}$ and $\mathrm{NO}$ ?. Thus, $\mathrm{HCC}$ for the oxidation of NO was carried out at electrode rotation rates from 250 to $400 \mathrm{rpm}$, and in this case the potential was stepped from 0 to $0.62 \mathrm{~V}$. The obtained HCC curves are shown in Fig. 3, in which it took about $1 \mathrm{~min}$ to obtain these all curves. For each curve, a linear regression was con-
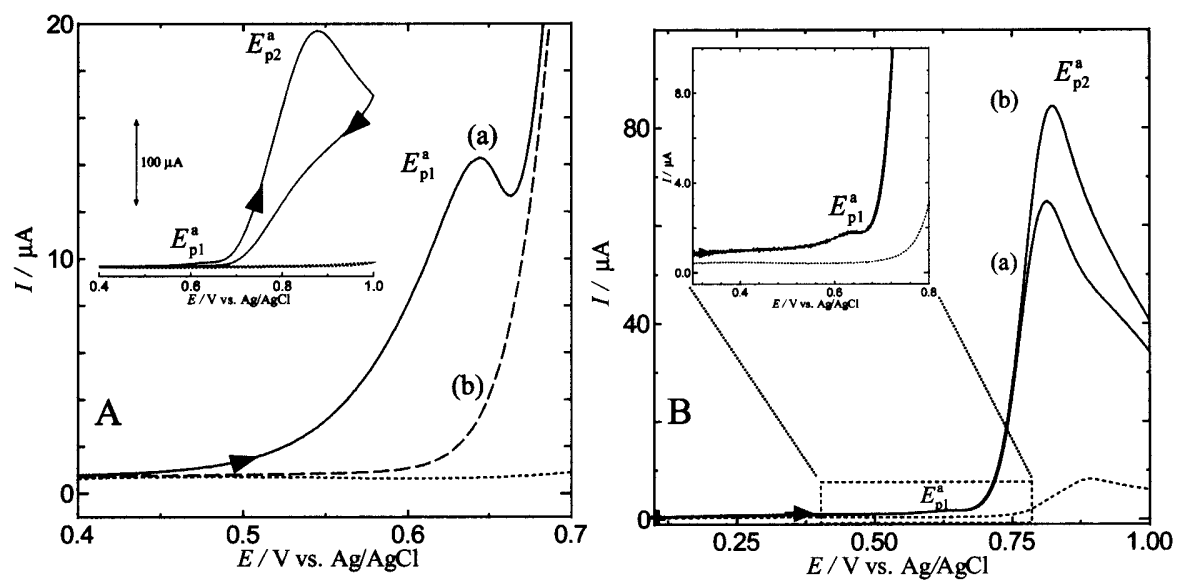

Fig. 1 (A) Typical voltammograms recorded at Au electrode (diameter, $d=1.6 \mathrm{~mm}$ ) in NO-saturated $0.1 \mathrm{M}$ phosphate buffer solution (pH 7.2) before (a, solid line) and after (b, dashed line) Ar gas was sufficiently (for ca. 10 min) purged into the solution. Dotted line shows the voltammogram corresponding to the background response recorded in Ar gas-saturated $0.1 \mathrm{M}$ phosphate buffer solution ( $\mathrm{pH} \mathrm{7.2)}$. Potential scan rate was $100 \mathrm{mVs}^{-1}$. Inset shows the entire voltammograms in the potential range between 0.4 and $1.0 \mathrm{~V}$. (B) Typical voltammograms obtained at $\mathrm{Au}(d=1.6 \mathrm{~mm})$ electrode in NO-saturated $0.1 \mathrm{M}$ phosphate buffer solution ( $\mathrm{pH}$ 7.2) in the absence (a) and presence (b) of $0.3 \mathrm{mM} \mathrm{NaNO}_{2}$. Potential scan rate was $100 \mathrm{mVs}{ }^{-1}$. Inset shows partially enlarged voltammograms. Dotted line represents the background response obtained in Ar gas-saturated $0.1 \mathrm{M}$ phosphate buffer solution ( $\mathrm{pH} 7.2)$. 


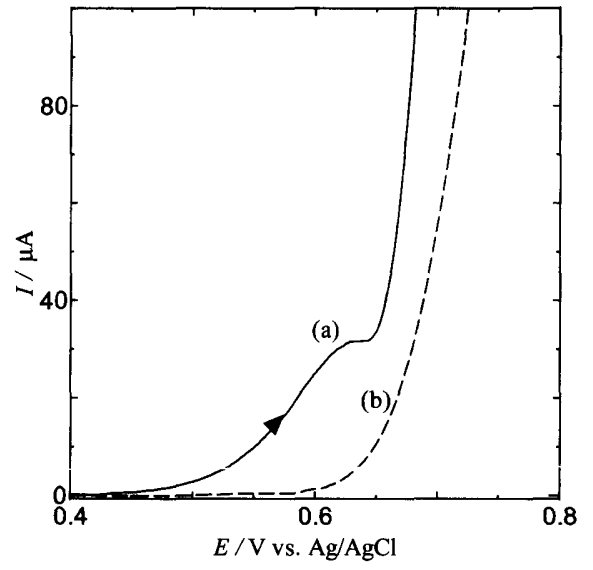

Fig. 2 Typical steady-state voltammograms recorded for the oxidation of $\mathrm{NO}$ at rotating $\mathrm{GC}$ disk electrode $(d=3.0 \mathrm{~mm})$ in NO-saturated $0.1 \mathrm{M}$ phosphate buffer solution ( $\mathrm{pH} \mathrm{7.2)} \mathrm{be-}$ fore (a, solid line) and after (b, dashed line) Ar gas was sufficiently (for $c a .10 \mathrm{~min}$ ) purged into the solution. Electrode rotation rate was $200 \mathrm{rpm}$. Potential scan rate was $1 \mathrm{mVs}^{-1}$.

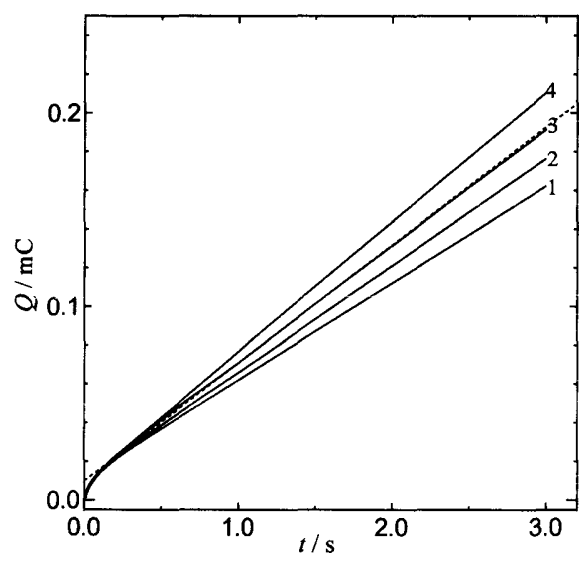

Fig. 3 Hydrodynamic chronocoulometric data of NO oxidation at rotating GC disk electrode $(d=3.0 \mathrm{~mm})$ in NOsaturated $0.1 \mathrm{M}$ phosphate buffer solution ( $\mathrm{pH} 7.2$ ). Electrode rotation rates: (1) 250 , (2) 300 , (3) 350 , and (4) $400 \mathrm{rpm}$. The potential of the working electrode was stepped from 0 to 0.62 $\mathrm{V}$ vs. $\mathrm{Ag} / \mathrm{AgCl}$. All the measurements were performed under Ar gas atmosphere. The dotted line shows the typical regression line obtained over the electrolysis time 1.2 and $1.5 \mathrm{~s}$ for the $Q$ vs. $t$ curve at $350 \mathrm{rpm}$.

ducted over the electrolysis time between 1.2 and $1.5 \mathrm{~s}$. The straight line obtained by such a linear regression (typically shown by the dotted line for the $Q$ vs. $t$ curve at $350 \mathrm{rpm}$ in Fig. 3) can be expressed by the following charge $(Q)$-time $(t)$ relationship:

$$
Q=Q_{\delta}+I_{\mathrm{L}} t
$$

with

$$
Q_{\delta}=0.3764 n F A C_{\mathrm{NO}} \delta, I_{\mathrm{L}}=\left(n F A D_{\mathrm{NO}} C_{\mathrm{NO}} / \delta\right)
$$

where $\delta$ is the thickness of the hydrodynamic boundary layer and is given by
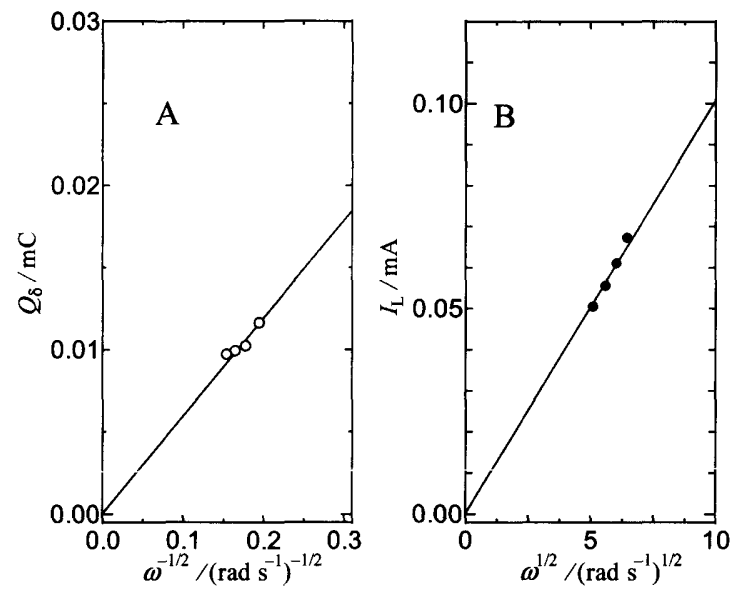

Fig. 4 (A) $Q_{\delta}$ vs. $\omega^{-1 / 2}$ plot and (B) $I_{L}$ vs. $\omega^{1 / 2}$ plot for the oxidation of NO in NO-saturated $0.1 \mathrm{M}$ phosphate buffer solution $(\mathrm{pH}$ 7.2). Data were taken from Fig. 3.

$$
\begin{aligned}
\delta= & 1.610 D_{\mathrm{No}}^{1 / 3} v^{1 / 6} \omega^{-1 / 2}\left(1+0.2980 S c^{-1 / 3}\right. \\
& \left.+0.14514 S c^{-2 / 3}\right)
\end{aligned}
$$

In Eqs. 7 and $8, n$ is the number of electrons involved in the electrode reaction, $F$ is the Faraday constant, $A$ is the electrode surface area, $v$ is the kinematic viscosity of the solution, $S c\left(=v / D_{\mathrm{NO}}\right)$ is the Schmidt number, and $\omega$ is the electrode angular velocity $(\omega=2 \pi f$, where $f$ is the frequency of the electrode rotation). Thus the values of slope $\left(I_{\mathrm{L}}\right)$ and intercept $\left(Q_{\delta}\right)$ estimated from Fig. 3 were plotted against $\omega^{1 / 2}$ and $\omega^{-1 / 2}$, respectively, as shown in Fig. $4 \mathrm{~A}$ and $4 \mathrm{~B}$. Both plots of $I_{\mathrm{L}}$ vs. $\omega^{1 / 2}$ and $Q_{\delta}$ vs. $\omega^{-1 / 2}$ were found to be satisfactorily linear and to pass through the origin, as expected from Eqs. 7 and 8. Then, assuming that NO undergoes a one-electron oxidation reaction (Eq. 4), ${ }^{11)}$ we could estimate the values of $D_{\text {No }}$ and $C_{\text {No }}$ using Eq. 7 . The similar experiments were performed with the pretreated $\mathrm{Au}$ and Pt electrodes. All the obtained results are summarized in Table 1, together with those previously reported.

The evaluated values of $C_{\mathrm{NO}}$ in $0.1 \mathrm{M}$ phosphate buffer solution ( $\mathrm{pH}$ 7.2) by HCC and Griess method are in good agreement with literature values in pure water ${ }^{13)}$ and phosphate buffer solution ${ }^{14)}$ which were determined by a conventional manometric-volumetric method and potential-step chronoamperometry, respectively.

The value of $D_{\mathrm{NO}}$ in $0.1 \mathrm{M}$ phosphate buffer solution was estimated to be $(1.2 \sim 1.3) \times 10^{-5} \mathrm{~cm}^{2} \mathrm{~s}^{-1}$, which is smaller than the values obtained by other researchers: $2.60 \times 10^{-5} \mathrm{~cm}^{2} \mathrm{~s}^{-1}$ in pure water, $3.30 \times 10^{-5} \mathrm{~cm}^{2} \mathrm{~s}^{-1}$ at $37^{\circ} \mathrm{C}$ in $10 \mathrm{mM}$ phosphate buffer solution and $(4.5 \pm 0.3)$ $\times 10^{-5} \mathrm{~cm}^{2} \mathrm{~s}^{-1}$ at $25^{\circ} \mathrm{C}$ in $50 \mathrm{mM}$ phosphate buffer solution, probably due to differences in experimental conditions such as temperature and concentration of buffer solution. We also simultaneously evaluated the values of $D_{\text {No }}$ and $C_{\text {NO }}$ in acidic electrolytic solution in which NO is more stable than in neutral or alkaline solutions. ${ }^{15,16)}$ The values of $D_{\mathrm{No}}$ and $C_{\mathrm{NO}}$ in $4 \mathrm{M} \mathrm{H}_{2} \mathrm{SO}_{4}$ were comparable to the values previously reported. ${ }^{16,17)}$

In conclusion, a simultaneous determination of $C_{\mathrm{NO}}$ and 
Table 1 The values of diffusion coefficient $\left(D_{\mathrm{NO}}\right)$ and concentration $\left(C_{\mathrm{NO}}\right)$ of NO in NO-saturated solutions.

\begin{tabular}{|c|c|c|c|c|c|}
\hline Electrodes & Electrolytes & $10^{5} D_{\mathrm{NO}} / \mathrm{cm}^{2} \mathrm{~s}^{-1}$ & $10^{3} C_{\mathrm{NO}} / \mathrm{M}$ & $\begin{array}{c}\text { Temperature } \\
/{ }^{\circ} \mathrm{C}\end{array}$ & Measurement Methods \\
\hline GC & $0.1 \mathrm{M}$ phosphate buffer (pH 7.2) & $1.20 \pm 0.17$ & $1.54 \pm 0.19$ & 25 & this work \\
\hline $\mathrm{Au}$ & $0.1 \mathrm{M}$ phosphate buffer ( $\mathrm{pH} 7.2)$ & $1.29 \pm 0.17$ & $1.72 \pm 0.13$ & 25 & this work \\
\hline $\mathrm{Pt}$ & $0.1 \mathrm{M}$ phosphate buffer ( $\mathrm{pH} 7.2$ ) & $1.22 \pm 0.15$ & $1.68 \pm 0.19$ & 25 & this work \\
\hline- & $0.1 \mathrm{M}$ phosphate buffer ( $\mathrm{pH} 7.2)$ & - & $1.80 \pm 0.10$ & 25 & this work $\left.{ }^{a}\right)$ \\
\hline $\mathrm{Pt}$ & $4 \mathrm{M} \mathrm{H}_{2} \mathrm{SO}_{4}$ & $0.59 \pm 0.25$ & $0.92 \pm 0.16$ & 25 & this work \\
\hline $\mathrm{Pt}$ & $2 \mathrm{M} \mathrm{H}_{2} \mathrm{SO}_{4}$ & 0.90 & 1.92 & 25 & RDE voltammetry \\
\hline Pt & $4 \mathrm{M} \mathrm{H}_{2} \mathrm{SO}_{4}$ & 0.90 & 1.29 & 23 & RDE voltammetryc) \\
\hline- & pure water & - & 1.9 & 25 & manometric-volumetric method ${ }^{d)}$ \\
\hline- & $\begin{array}{c}\text { acidified saline }\left(9 \mathrm{mg} \mathrm{ml}^{-1} \mathrm{NaCl} \text {, }\right. \\
0.1 \mathrm{mM} \mathrm{HCl}, \mathrm{pH} 4)\end{array}$ & - & 3 & 25 & Griess methode) \\
\hline- & pure water & 2.60 & - & 25 & microscopic observation ${ }^{\mathrm{f}}$ \\
\hline carbon fiber & $\begin{array}{c}\text { buffer solution (10 mM phosphate, } \\
2.7 \mathrm{mM} \mathrm{KCl}, 137 \mathrm{mM} \mathrm{NaCl} \\
1 \mathrm{mM} \mathrm{L} \text {-arginine, } \mathrm{pH} 7.4)\end{array}$ & 3.30 & - & 37 & amperometryg) \\
\hline carbon fiber & phosphate buffer (pH 7.4) & - & $1.74 \pm 0.03$ & 37 & $\begin{array}{l}\text { potential-step } \\
\text { chronoamperometryh) }\end{array}$ \\
\hline- & $0.05 \mathrm{M}$ phosphate buffer ( $\mathrm{pH} 7.4$ ) & $4.5 \pm 0.3$ & - & 20 & fluorophotometric analysis ${ }^{\mathrm{i}}$ \\
\hline
\end{tabular}

\footnotetext{
a) The estimation of $C_{\text {NO }}$ was performed by a combined use of Griess method and electroanalytical method. ${ }^{8)}$

b) Ref. 15), the $C_{\text {NO }}$ was evaluated using the $D_{\text {No }}$ taken from Ref. 16).

c) Ref. 16$)$, the $D_{\text {NO }}$ was evaluated using the $C_{\text {NO }}$ which was previously obtained by a potentiometric titration.

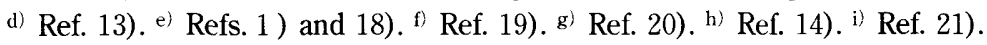

$D_{\mathrm{No}}$ in physiological $\mathrm{pH}$ solution has been for the first time carried out using hydrodynamic chronocoulometry with electrochemically pretreated GC, $\mathrm{Pt}$ and $\mathrm{Au}$ electrodes under the experimental condition that $\mathrm{NO}$ and its oxidized species ( electroactive $\mathrm{NO}_{2}{ }^{-}$) coexist.

\section{Acknowledgement}

The present work was financially supported by Grantin-Aids for Scientific Research on Priority Areas (No. 417), Scientific Research (A) (No. 10305064), and Scientific Research (No. 12785164) from the Ministry of Education, Culture, Sports, Science, and Technology, Japan.

\section{References}

1) S. Archer, FASEB J., 7, 349 (1993).

2) M. Tsushima, K. Tokuda, and T. Ohsaka, Anal. Chem., 66, 4551 (1994).

3) T. Ohsaka, M. Tsushima, T. Okajima, and K. Tokuda, Denki Kagaku (presently Electrochemistry), 62, 1300 (1994).

4) J. F. Wu, Y. Che, T. Okajima, F. Matsumoto, K. Tokuda, and T. Ohsaka, Anal. Chem., 71, 4056 (1999).

5) F. Pariente, J. L. Alonso, and H. D. Abruna, J. Electroanal. Chem., 379, 191 (1994).

6) R. M. J. Palmer, A. G. Ferrige, and S. Moncada, Nature, 327, 524 (1987).

7) N. Spataru, T. N. Rao, D. A. Tryk, and A. Fujishima, J. Electrochem. Soc., 148, E 112 (2001).

8) T. Oritani, T. Okajima, F. Kitamura, and T. Ohsaka, J.
Kor. Elecrochem. Soc., 5, 209 (2002).

9) D. A. Wink and J. B. Mitchell, Free. Rad. Biol. Med., 25, 434 (1998).

10) Y. Izumi, D. M. Clifford, and C. F. Zorumski, Science, 257, 1273 (1992).

11) M. Maskus, F. Pariente, Q. Wu, A. Toffanin, J. P. Shapleigh, and H. D. Abruna, Anal. Chem., 68, 3128 (1996).

12) B. Piela and P. K. Wrona, J. Electrochem. Soc., 149, E 55 (2002).

13) A. W. Shaw and A. J. Vosper, J. Chem. Soc. Faraday. Trans. I, 1977, 1239.

14) S. Mesaros, S. Grunfeld, A. Mesarosova, D. Bustin, and T. Malinski, Anal. Chim. Acta, 339, 265 (1997).

15) I. Paseka and J. Vonkova, Electrochim. Acta, 25, 1251 (1980).

16) D. Dutta and D. Landolt, J. Electrochem. Soc., 119, 1320 (1972).

17) W. J. Plieth, Chapter viii-5: Nitrogen, in: A. J. Bard (Ed.), Encyclopedia of Electrochemistry of the Elements, Marcel Dekker, New York (1973).

18) W. R. Tracey, J. Linden, M. J. Peach, and R. A. Johns, J. Phrmacol. Exp. Ther., 252, 922 (1990).

19) D. L. Wise and G. Houghton, Chem. Eng. Sci., 23, 1211 (1968).

20) T. Malinski, Z. Taha, S. Grunfeld, S. Patton, M. Kapturczak, and P. Tomboulian, Biochem. Biophys. Res. Commun., 193, 1076 (1993).

21) A. Denicola, J. M. Souza, R. Radi, and E. Lissi, Arch. Biochem. Biophys., 328, 208 (1996). 